\title{
AN ATHEISTIC ARGUMENT FROM UGLINESS
}

SCOTT F. AIKIN \& NICHOLAOS JONES

Vanderbilt University University of Alabama in Huntsville

Author posting. (c) European Journal of Philosophy of Religion 7.1 (Spring 2015).

This is the author's version of the work. It is posted here for personal use, not for redistribution.

The definitive version is available at http://www.philosophy-of-

religion.eu/contents19.html

This is a penultimate draft. Please cite only the published version.

\section{Abstract}

The theistic argument from beauty has what we call an 'evil twin', the argument from ugliness. The argument yields either what we call 'atheist win', or, when faced with aesthetic theodicies, 'agnostic tie' with the argument from beauty. 


\section{AN ATHEISTIC ARGUMENT FROM UGLINESS}

\section{EVIL TWINS FOR TELEOLOGICAL ARGUMENTS}

The theistic argument from beauty is a teleological argument. Teleological arguments take the following form:

1. The universe (or parts of it) exhibit property $X$

2. Property $X$ is usually (if not always) brought about by the purposive actions of those who created objects for them to be $X$.

3. The cases mentioned in Premise 1 are not explained (or fully explained) by human action

4. Therefore: The universe is (likely) the product of a purposive agent who created it to be X, namely God.

The variety of teleological arguments is as broad as substitution instances for $X$. The standard substitutions have been features of the universe (or it all) fine-tuned for life, or the fact of moral action. One further substitution has been beauty. Thus, arguments from beauty.

A truism about teleological arguments is that they have evil twins. Reality is a mixed bag, so for every argument from fine-tuning, there is an argument that shows how very little of the universe is inhabitable for living creatures and how poorly designed many of these creatures are. For every case from the fact of moral action, there is a case from immoral action. This is the evil twin problem for teleological arguments.

We will pose the evil twin problem for the argument from beauty, so an argument from ugliness. The general strategy of evil twins will be in effect: either play for atheist win or for agnostic tie. To play for atheist win, one may, parallel to the argument from evil, attribute evil or complicity with evil to god, and thereby prove that he cannot be god proper. To play for agnostic tie, the case is that whatever means the theist would use to dismiss evil twin cases can be used against the good cases, too. Consequently, teleological arguments are a wash.

First, we will outline the argument from beauty in its various instantiations. Second, we will pose the problem of ugliness. Third, we will play for atheist win. Fourth, we will consider a few strategies for aesthetic theodicy, but they allow us to play for agnostic tie.

\section{ARGUMENT FROM BEAUTY}

The theistic argument from beauty has been around at least since Hesiod, who explains the grandeur of the world as a product of Gaia's love (Theogony, II.120). Plato, too, invokes the divine to account for beauty (Symposium, 210a-212c). Augustine gives an explicit version of the argument in the Confessions: 'We look upon the heavens and earth, and they cry aloud that they were made. ... It was You, Lord, who made them: for You are beautiful, and they are beautiful....' (XI. 4) 
In short: God's greater beauty explains the beauty of creation. In the twentieth century, F.R. Tennant gave a version of the argument from beauty, noting that the world is 'saturat[ed]' with beauty (1928: 91). Nature, Tennant infers, must then be the product of a mind with intentions of aesthetic fulfilment. Mark Wynn, extending Tennant's line of thought, notes that: 'Most believers ... are more likely to be impressed by the beauty of nature, when considering whether the world answers to providential purpose, than by mere regularity or order.' (1999: 15)

Wynn, however, is modest about how much the case from beauty can actually prove by itself, as it cannot be 'persuasive in isolation from other arguments' (1999: 36). Regardless, Wynn does take it to be a positive case. ${ }^{1}$

Finally, Richard Swinburne holds that 'God has a reason to create a beautiful inanimate world - that is, a beautiful physical universe' (2004: 121). God, being the source of good, will be instrumental in producing as much good in as many varieties as possible. So, if God creates a universe, it will be beautiful. Since the universe is beautiful (and a universe without a creative god would likely not be quite as beautiful as this one), we have reason to believe that God exists and has aesthetic values (2004: 190).

\section{ARGUMENT FROM UGLINESS}

The general problem for teleological arguments is that the world is a mixed bag. There is order, pleasure, goodwill, and beauty aplenty. There is also disorder, pain, hate, and ugliness too. To deny that is blinkered nonsense. ${ }^{2}$ If we reason from effects to cause, then the cause of the universe, on the assumption we are attributing either the properties of the effects or the intention to cause these effects to the cause, will likely be a mixed bag too.

The argument from ugliness, too, has a pedigree. Plato saw it as a stalking horse to his theory of forms, and in the Parmenides, Socrates is challenged with the question whether there is a form for hair, dirt, or mud (130a-c). Marcus Aurelius notes the incoherence of his two related Stoic exercises of invoking 'disgust at what things are made of: liquid, dust, bones, filth' (Meditations, 9:36) but also appreciating the beauty in 'Nature's inadvertence' (Meditations, 3:2). William Blake's 'The Tyger' closes with the question: 'What immortal hand or eye dare frame thy fearful symmetry?'

\footnotetext{
${ }^{1}$ We should note here, perhaps, a corollary to our evil twin observation: evil twin arguments can be only as strong as the arguments to which they are twins. And so, if the argument from beauty itself is not a full case for God's existence, then the argument from ugliness can't be a full case either.

${ }^{2}$ Consider Schopenhauer's line on this thought: 'If we were to conduct the most hardened and callous optimist through hospitals, infirmaries, operating theatres, through prisons, torturechambers, and slave hovels, over battlefields and to places of execution; if we were to open to him all the dark abodes of misery, where it shuns the gaze of cold curiosity, and finally were to allow him to glance into the dungeon of Ugolino where prisoners starved to death, he too would certainly see in the end what kind of a world is this meilleur des mondes possible [best of all possible worlds]' (1969: 325).
} 
The argument from ugliness, like that from beauty, begins with cases. Consider terrible art, perhaps songs by the 1980 's rock group Ratt or Thomas Kinkade paintings. They are things merely to endure. Take the harsh call of crows, or the unsightly leaking of sap from a splintered tree limb. Consider the human form and the insipid and unwieldy elbow - even the most graceful can only but manage its awkward hinged angularity. The anglerfish of the deep and the aruana of the Amazon are hideous creatures. Mountain vistas may be beautiful, but they are few and far between. In the in-between, there are sticky and stinky swamps, boring groupings of trees, misplaced shrubbery, and intermittent villages filled with sticky and stinky children. Yuck. And, of course, there is vomit, puss, bile, phlegm, and faeces. It all, like impressionist painting, is tolerable only from very far away.

Why so much ugliness? Is it that there is a god who has upside down aesthetic sensibilities and wishes to impress them upon us? Is god ugly and that causes earthly ugliness? On the argument from beauty, God is beautiful or prefers beautiful things, and so there is beauty in the world. So, on the ugliness argument, perhaps God, given ugliness, does the same thing and serves up so much hideous business. Or, perhaps, instead of liking the ugly, God detests it and provides a healthy serving of ugly for us because he hates us. After all, Jesus heals lepers, the blind, and the lame-but not the ugly. The argument from evil is famously turned into a kakodaimonia argument, and so may the argument from ugliness: given the amount of ugly in the world, we have reason to believe that God either loves ugliness, is ugly, or hates us and tortures us with ugliness. ${ }^{3}$ Given that God must be a unity of good things, a God satisfying any of those three disjuncts cannot be God. Atheism wins.

\section{STANDARD THEODICIES}

Theodicy is the project of blocking inferences from the mixed bag of creation to the mixed nature of God. The problem of evil is that the case from evil has God either himself evil or at least complicit with it. The problem of ugliness has God either ugly himself or complicit in its creation. Theodicies deal with evil twins either as necessary means or as unavoidable by-products of their positive teleology. While there are many variations, we will mention just a few before offering their evil, ugly stepsisters. This should suffice for conveying the general spirit of playing for agnostic tie.

Necessary Counterpart theodicy. There could be no beauty without ugliness. For a world in which all things are beautiful is a world in which nothing distinguishes the beautiful from the non-beautiful; and if there is no such distinction, then there are no beautiful things. Since it is the nature of a good God to create a beautiful world, any world (like ours) that God creates must also contain ugly things.

Free Will theodicy. We are free agents, by virtue of God-granted free will. This free will allows for important goods, such as morally responsible action, compassion, and the creation of beauty. An unavoidable consequence of free will, however, is that we sometimes choose to perform actions that generate ugliness: we eat too many beans and fart, play instruments unskilfully and produce cacophony, cut corners and cause oil

\footnotetext{
${ }^{3}$ See, for example, Stephen Law's 'Evil God Challenge' (2010)
} 
spills, object to the 'establishment' and mount elephant shit in an art display. God could have created us without free will, thereby preventing choices that create ugliness, but the goods that God allows through granting free will more than outweigh the cost of ugliness.

Character-Building theodicy. Ugliness revolts us. However, since God is a unity of good things, God intends experiences of ugliness to be of benefit to us. Such benefit occurs when we take advantage of the opportunities experiences of ugliness offer us for developing valuable character traits. Perhaps God makes people ugly to give us an opportunity to be drawn to them by love rather than lust, or for them to learn to be happy with the way they are. Rumi seems to hold that experiences of ugliness offer us the chance to change our perspective and to acknowledge God's omnipotence and generosity: 'Both kinds of pictures (beautiful pictures and pictures devoid of beauty) are evidence of His mastery. The ugly ones are not evidence of his ugliness, they are evidence of His bounty.' (1926: 352)

Brady argues that experiences of ugliness have epistemic value because 'they increase our "aesthetic intelligence" through the development of an engaged appreciative awareness of ugliness and all forms of aesthetic value' (2010: 39).

Laws-of-Nature theodicy. A world that behaves in regular and orderly ways permits effective, purposeful action. Hence, the existence of laws of nature is necessary for our having abilities to interact with our environment and with each other. These interactions allow for great goods, such as kindness, stewardship, and so on. However, a law-governed world inevitably produces some ugliness. For instance, the kind of laws that govern digestion also sometimes produce flatulence and decomposition. This ugliness, however, is more than outweighed by the benefits of a law-governed world.

Perspectival theodicy. God, who is a unity of good things, created us with limited epistemic capacities. An unavoidable consequence of our finitude is that we cannot experience creation as a unified whole. There are areas on paintings that, when considered in isolation, strike us as ugly, even though they are beautiful when considered holistically. Similarly, were we able to enlarge our perspective, we would realize with the theologian Said Nursi that disasters and other evils act as divine reminders, by warning us from peril, cleansing us of sin, or awakening us to divine presence (Saritoprak 2005: 27). For, as the Quran says, God 'made beautiful everything that He created' (32:7). And, as Bette Midler sings, 'From a distance, there is harmony, and it echoes through the land.' Ugliness, accordingly, is an unavoidable consequence of our limited perspectives.

\section{REVERSE THEODICIES}

Reverse theodicy is the project of constructing formal counterparts to standard theodicies in order to undermine the cogency of those theodicies. The project involves constructing accounts of why beauty is a necessary means for or unavoidable byproduct of the existence of ugliness. These accounts, like those involved in standard theodicies, block inferences from the mixed bag of creation to the mixed nature of God - except, instead of blocking inferences to the claim that God is a unity of good things, 
they block the inference to the claim that God neither loves ugliness, is ugly, nor hates us and tortures us with ugliness.

Necessary Counterpart reverse-theodicy. There could be no ugliness without beauty. For a world in which all things are ugly is a world in which nothing distinguishes the ugly from the non-ugly; and if there is no such distinction, then there are no ugly things. Since if God either loves ugliness, is ugly, or hates us and tortures us with ugliness, it is the nature of God to create an ugly world, any world (like ours) that God creates must also contain beautiful things.

Free Will reverse-theodicy. We are free agents. This free will allows us to torment each other in ways that non-autonomous beings cannot. Consider William Edward Hickman, the model for the fictional hero Danny Renehan in Ayn Rand's unfinished novel The Little Street. In 1927, Hickman kidnapped the 12-year-old daughter of a banker, ransomed her for $\$ 1500$, drove away from the ransom exchange with the daughter, dumped her body-dead, with her legs chopped off, internal organs removed, torso drained of blood and stuffed with towels, and eyes wired open-from his car, and strew her organs throughout the Los Angeles area. The girl's body, when found, was ugly (to put it mildly). And what makes the sight especially repulsive is that someone deliberately mutilated her body: this was no accident, but rather the result of a process that, at any moment, Hickman could have stopped. Hickman's choice in the matter makes the situation especially depraved and the ugliness of the girl's body especially tragic. This special tragedy and depravity would not have been possible had Hickman lacked free will. An unavoidable consequence of free will, however, is that we sometimes choose to perform actions that generate beauty. Morticians, for example, sometimes choose to present corpses as radiant and peaceful. God could have created us without free will, thereby preventing choices that create beauty, but the ugliness that God allows through granting free will more than outweighs the cost of beauty.

Character-Destroying reverse-theodicy. If God either loves ugliness, is ugly, or hates us and tortures us with ugliness, God intends experiences of beauty to torment us. In 'The World Is Ugly, Don't You Know' My Chemical Romance sings of the anguish of unrequited love:

The world is ugly, But you're beautiful to me.

Are you thinking of me?

Are you thinking of him?

Majestic mountains and pristine rivers foster bickering about conservation. Beautiful children foster parental anguish about injury or harm; beautiful bodies foster stress about aging and death. If there were not some beauty in the world, we would not be so tormented by ugliness (Cf. Law 2010: 6).

Laws-of-Nature reverse-theodicy. A world that behaves in regular and orderly ways permits effective, purposeful action. Hence, the existence of laws of nature is necessary for our having abilities to interact with our environment and each other. These interactions allow for creation of ugliness: the stripping of mountainsides, the mangling 
of healthy bodies, and so on. However, a law-governed world inevitably produces some beauty. For instance, the laws that govern human physiology also sometimes produce a Mona Lisa or a Beethoven-like symphony. This beauty, however, is more than outweighed by the benefits of a law-governed world.

Perspectival reverse-theodicy. God, who either loves ugliness, is ugly, or hates us and tortures us with ugliness, created us as finite creatures with limited epistemic capacities. An unavoidable consequence of our finitude is that we cannot experience creation as a unified whole. Were we able to enlarge our perspective, we would realize that elements of the world that strike us as beautiful are, when considered holistically, ugly. Whence Camille Paglia:

An apple tree laden with fruit: how peaceful, how picturesque. But remove the rosy filter of humanism from our gaze and look again. See nature spuming and frothing, its mad spermatic bubbles endlessly spilling out and smashing in that inhuman round of waste, carnage, and rot. (1990: 28)

Beauty, accordingly, is an unavoidable consequence of our limited perspectives. For, as Schopenhauer says, 'as with all inferior goods, human life is covered with false glitter on the outside: what suffers always hides itself'(1969: 383-384)

These reverse theodicies are not intended to be effective defences of the claim that God either loves ugliness, is ugly, or hates us and tortures us with ugliness. Rather, they are intended to explain away the existence of beauty in a way similar to the way standard theodicies explain away the existence of ugliness. The similarity of the explanations indicates that there is no good reason to treat the reverse theodicies differently than the standard theodicies, so that the two kinds of theodicy are equally effective (by virtue of being not at all effective or effective to the same degree). In either case, it follows that the standard theodicies fail to block inferences from the mixed bag of creation to the mixed nature of God. This suffices for agnostic tie.

We have not, of course, reversed all possible theodicies. But the general strategy for reverse theodicy is exportable: first, substitute mentions of beauty with ugliness (and vice versa); then identify supporting cases. The strategy is effective for any prima-facie reasonable theodicy, we conjecture, because the variety of ugliness in the world ensures suitable examples. This is just the problem with standard theodicies: because of the variety of beauty in the world, there will be supporting cases for prima-facie reasonable claim regarding the necessity or unavoidability of ugliness. In light of the reverse theodicies, however, these examples do not help to explain away the existence of ugliness, and so do not clear the path from the existence of beautiful things to the existence of a beautiful God who creates those beautiful things.

\section{BIBLIOGRAPHY}

Augustine. 1993. The Confessions, trans. F.J. Sheed (Indianapolis: Hackett) Aurelius, Marcus. 2002. Meditations, trans. Gregory Hays (New York: Modern Library) Blake, William. 1971. Songs of Innocence and Experience (New York: Avon Books) Brady, Emily. 2010. 'Ugliness and Nature,' Enrahonar, 45: 27-40 
Hesiod. 1987. The Works and Days, Theogony, the Shield of Herakles, trans. R. Lattimore (Ann Arbor: Ann Arbor Paperbacks)

Law, Stephen. 2010. 'The Evil-God Challenge,' Religious Studies, 46: 353-73

Paglia, Camille. 1990. Sexual Personae: Art and Decadence from Nefertiti to Emily Dickinson (New Haven: Yale University Press)

Plato. 1996. Parmenides, trans. M.L. Gill (Indianapolis: Hackett)

Plato. 1989. Symposium, trans. A. Nehamas and P. Woodruff (Indianapolis: Hackett)

Rumi, Jalaluddin. 1926. The Mathnawi of Jalalu'ddin Rumi, Vol. 2, trans. Reynold A. Nicholson. (London: E.J.W. Gibb Memorial Trust)

Tennant, F.R. 1928. Philosophical Theology (Cambridge: Cambridge University Press)

Saritoprak, Zeki. 2005. 'The Creation of Evil is not Evil: Nursi's Theological Approach to the Existence of Evil,' Fountain: A Magazine of Critical Scientific and Spiritual Thought, 50: 26-8

Schopenhauer, Arthur. 1969. The World as Will and Representation, Vol. 1., trans. E.F. Payne (New York: Dover)

Swinburne, Richard. 2004. The Existence of God, 2nd edition (New York: Oxford University Press)

Wynn, Mark. 1999. God and Goodness: A Natural Theological Perspective (New York: Routledge) 